\title{
Hybrid Political Order in Libya: State, Non-State, and Armed Actors
}

\author{
MURAT ASLAN \\ Hasan Kalyoncu University, Turkey \\ ORCID No: 0000-0002-5128-1020
}

ABSTRACT Libya, inspired by the February 17 revolution but devastated by post-revolt challenges, is struggling to build order, as state, non-state, and external actors exacerbate the already fragile security environment. Among these actors, state and non-state actors pose a repeating and paradoxical dilemma. Libya's post-Qaddafi state structure has been formed by non-state armed actors, and at the same time these actors threaten the survival of the state; certain non-state armed groups compete against each other to accumulate more power, while in some cases being legitimized and funded by the state itself. The root causes of this paradoxical situation can be scrutinized by investigating the security culture inherited from Qaddafi's regime, particularly its inefficient and ignored security institutionalization, and the efforts of the competing armed groups to dominate their areas of influence in the absence of a coherent state structure.

Keywords: Reform, Security, Libya, Non-State Actors, Armed Groups 


\title{
Introduction
}

\begin{abstract}
ibya is not a new state; it has a deep history with customs typical of the Maghreb. When compared to most states, Libya has a highly educated population and natural resources that may yet facilitate a state of prosperity and stability. ${ }^{1}$ Despite Libya's potential, the February 17 Revolution's weakly organized structure, in addition to the security culture inherited from the Qaddafi regime, caused major shortcomings in the 'new' state. Such a shortage of civic security thinking and architecture coincided with the revolution of 2011 whereby various militias in Libya were able to topple the regime and disperse or destroy the 'poorly existing' secured environment in 'their' portion of the country. ${ }^{2}$ Eventually, fluctuating, non-institutionalized, and disorganized security establishments emerged, challenging each other and the legitimate authority alike.
\end{abstract}

This study reviews Libya's security picture and explores how its fragmented state structure encourages the proliferation of non-state armed groups, which, consequently, at times challenge the state itself. In this sense, the roots of today's insecure Libya are the consequences of the practices of the state itself. The argument will begin by investigating the inherited legacy of Qaddafi-era practices, the revolution of 2011 and its consequences regarding the countrywide militia formation and the inter-linkage between the state structure and the militia that perpetuates sustainable insecurity. The methodology of this study is based on interviews with Libyans who have/had prominent roles either during the revolution and/or in the current state/security structure. ${ }^{3}$ The interviews have been crosschecked against each other and compared to the literature.

\section{A Brief History of Libya's Security Institutions: The Legacy of the Qaddafi Era}

It is a valid argument that the genesis of the post-revolution crisis in Libya emanates from the past practices of the Qaddafi era, practices based on the unfair treatment of Libyans, discrimination against anti-Qaddafi societal formations and Qaddafi's disabling of Libya's security organizations to ensure his regime's survival. ${ }^{4}$ In order to understand how Qaddafi's attitude and logic were shaped, we need to present a short history of Libya's security forces in order to understand what was established during and inherited from the Qaddafi era, and what emerged afterwards. ${ }^{5}$

\section{The Libyan Armed Forces}

After the establishment of independent Libya on December 24, 1951, the Libyan government began the efforts of restructuring the Libyan Armed Forces ${ }^{6}$ on August 9, 1952 and established a military academy in Zawiya for officers' 
training and education, which was fully inaugurated in 1957, as an alternative to the Royal Academy in Benghazi. In parallel to this initiative in training and education, the Libyan Navy was established in 1962 and the Libyan Air Force in 1968. The initial years of forming the Armed Forces were committed

\section{The 1969 al-Fateh "Revolution" (also known as the September 1 Revolution) was initiated by a group of young soldiers, who called themselves the 'Free Officers'} to producing well-disciplined and high-ranking soldiers with advanced skills as a nucleus for future security forces; however, the institutions lacked an adequate level of resources. Training and education were the critical issues, since the established academies had a limited capacity to graduate skilled officers. For this reason, Libya sent officers and cadets abroad for training in 1963. Turkey was an important destination, and Libya also brought General Umran Caba from the cadre of the Turkish Armed Forces, into the country to restructure the Libyan Armed Forces. ${ }^{7}$

The 1969 al-Fateh "Revolution" (also known as the September 1 Revolution) was initiated by a group of young soldiers, who called themselves the 'Free Officers.' Their intention had apparently been suspected by the Kingdom's Office, and they were kept under observation by the Ministry of Defense. The Ministry did not have concrete proof but suspected them of planning a coup d'état and formed a military intelligence commission to clearly ascertain their intention. However, some members of the Commission were also members of the Free Officers. The infiltration of the chain of command by the Free Officers ensured the success of the al-Fateh coup, which was justified by alleging 'the risk of being occupied by a foreign force.' The coup seized on the opportunity offered by the consolidation of the Armed Forces, which had taken place earlier in $1969 .^{8}$

Qaddafi instigated al-Fateh coup from the emerging and consolidated armed forces, which were small in number but militarily capable. Ironically, Qaddafi, like King Idris I, whom he deposed, perceived the military as a threat to his reign. Hence, he designed a strategy to create a huge but hollow Armed Forces. The number of officers increased from 650 to over 17,000, while recruits increased from 1,000 to 120,000 in 42 years. Qaddafi initiated a loosening in the unity of command in the Armed Forces, encouraging soldiers not to execute their assigned tasks and replacing competent personnel with unqualified staff. ${ }^{9}$ As an extension of Qaddafi's strategy, more officers were recruited and given titles in order to balance different groups. For 42 years, the superior positions of the Armed Forces were held by the same individuals, who represented Libya's inter-tribal connections. Outside of the neglected and disengaged Armed Forces, Qaddafi established Special Protection Units for his safety alone. ${ }^{10}$ 


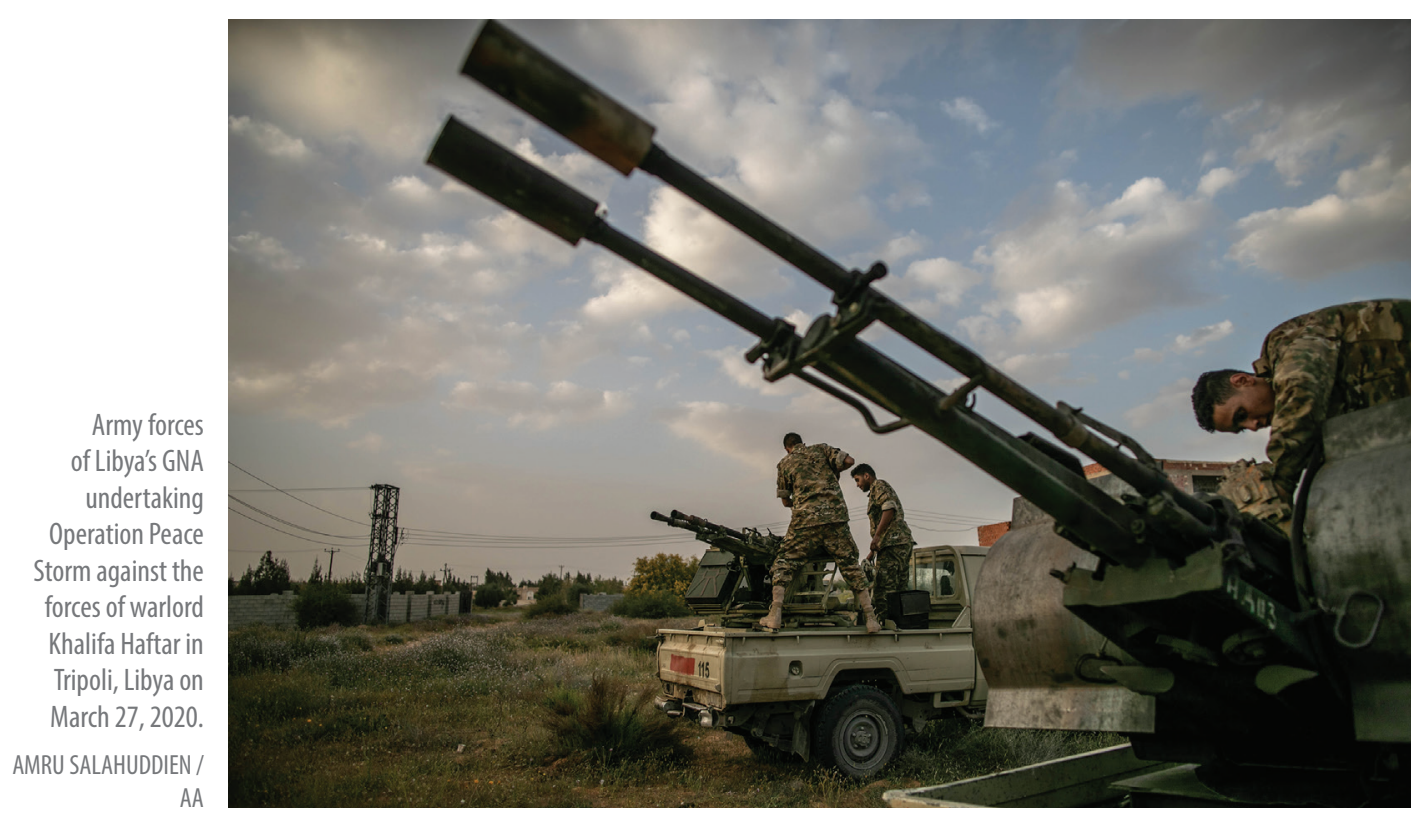

The years 1987-1988 appear to be a turning point in Qaddafi's evolving strategy of ensuring that the Army was softened in order not to pose a threat to him. He formed the "Popular Guard" with a supposed 'new thinking' and dissolved the existing Army. ${ }^{11}$ He established councils and assumed the authority of commanding the Armed Forces in the name of the Libyan people along with the Revolutionary Command Council. The new system required people to have arms and mobilize themselves in case of a threat -this would later be a major cause of the formation of urban- based militias during and after the 2011 Revolution. ${ }^{12}$

The 1980s witnessed Qaddafi's imperialistic ambitions. With progressively accumulating oil revenues, Qaddafi began an arms procurement program and committed himself "to saving Chad." ${ }^{13}$ Chad marked the initial phase of a longterm campaign for Qaddafi, who had a vision in his mind to unite all of Africa, leading him to create a huge army. He conscripted almost all Libyans to the Armed Forces between 1977 and 1987, although most members of the Libyan community had no desire to be soldiers. ${ }^{14}$

The Chad campaign, itself, became a challenge for the Libyan Armed Forces, which withdrew after being defeated in 1986. Qaddafi sent Khalifa Haftar to Dom Valley to retaliate and recapture the lost territory. Eventually the Chadian forces defeated the Haftar-led Army and the strategy collapsed. ${ }^{15}$ This critical setback led Qaddafi to invent a new method of gaining influence in Africa: bribery. The leaders of poor African countries received direct payments from 
Qaddafi every three months according to a former aide of Qaddafi. With this strategy, Qaddafi realized that there was no need to have an 'Armed Forces.' ${ }^{16}$ He built a Protection Force for himself alone, and let the soldiers stay at home while maintaining monthly wages to ensure that they were not a risk to his regime. ${ }^{17}$ The new perception among the public was that the Armed Forces were under the command of Abu Bakr Yunis Jabr, the Minister of Defense under Qaddafi, while the Protection Units were Qaddafi's Army. ${ }^{18}$

\section{Armed groups had to fill the vacuum by building their own institutions to fill in for the police by means of newly established organizations like the Supreme Security Committee, Rapid Reaction Forces, and the Security Councils}

Qaddafi's strategy was based on maintaining the image of his indispensability to sustaining internal order and to consciously sow chaos in certain locations to remind the public that he was vital to maintaining order and making things better. Moreover, he continually changed the security system to build a 'new and functional' one, which both shook the established security order and challenged the societal structure. ${ }^{19}$

Operating under these conditions, the Libyan Armed Forces were discredited in the eyes of the public and lacked the capacity to operate as a functioning military structure. In 2011, the Armed Forces were hollow, with ranks and positions distributed because of personal connections, lacking logistics, and numbering a mere 120,000, compared to Qaddafi's well-equipped and staffed Protection Force. It took only eight months to destroy Qaddafi's security structure, while the incapacitated Armed Forces oscillated between providing support to the revolutionaries, to Qaddafi or remaining neutral to 'wait and see' who would be the victor. ${ }^{20}$ Qaddafi's violent suppression of the protests gave impetus to the revolution and quickly resulted in the formation of Military Councils to resist him. The councils were comprised of both regular military officers who had joined the revolution and civilian members of the armed groups. ${ }^{21}$

\section{The Libyan Police}

The Ottomans had built a police force in Libya as part of their judicial and security architecture. ${ }^{22}$ The occupying Italians dissolved the police in 1911 and built their own system by appointing military personnel responsible for public order. When the Italians withdrew from Libya in 1943, the British took charge of organizing and managing the Libyan police until 1951. Although the British policing system was applied in Tripoli and Cyrenaica between 1943 and 1951, the Fezzan region still used the Ottoman system. After the 
It was alarming to see tribalism, regionalism, and benefit-based formations that surpassed the obtained advantages of freedom after Qaddafi's diminishing regime discovery of oil, the police force was organized within a federal model with different forces linked to a central authority. The most important function of the police was to monitor foreigners and immigration in accordance with the climate of the Cold War era. The year 1963 saw the transformation of the federal structure to a centralized one due to increasing income from oil exports. ${ }^{23}$

Qaddafi's coup d'état, al-Fateh revolution, handed command of the police to the military. The same methods of defunctionalizing the Armed Forces were applied to the police forces after Qaddafi's coup. The conception of a "Popular Guard" for the Armed Forces was contemplated for the police forces with a similar concept of "self-security by the people," which would also be the basis of forming militias after the 2011 Revolution. ${ }^{24}$ The commanding cadre were appointed according to their loyalty to the regime. Similarly to the Army, reform and transformation attempts to revitalize the police were undertaken every three to four years, devastating the previously established security architecture.

The February 17 Revolution was complicated for the police compared to the military. The non-committal approach of the police led to a security gap after the revolution. Armed groups had to fill the vacuum by building their own institutions to fill in for the police by means of newly established organizations like the Supreme Security Committee, Rapid Reaction Forces, and the Security Councils. These Councils provided security by recruiting former police officers and members of armed groups who had joined the revolution, in a manner similar to the Military Councils.

\section{February 17 Revolution: Success or Failure?}

\section{Anatomy of the Revolution}

Opinions on the motivations for the revolt differ among Libyans. Anti-authoritarianism has become a common argument, although a structuralist perception may claim the Arab spring and its efforts to obtain more rights and prosperity as the motivating factor. It may be argued that the revolution was caused by a combination of many factors. Generally, there was an accumulated hatred against the regime among society at large due to extreme pressure, injustice and suppression of free speech and religious freedom. A prominent Libyan scholar claims that limits on the free practice of religion were an issue, reflecting his worldview and justification for participating in the revolution. 
Access to weapons and ammunition turned the peaceful demonstrations into an armed resistance once the regime chose violent tactics to suppress demonstrations after Friday prayers before the revolution. ${ }^{25}$

Essentially, the revolution started in the East and expanded toward the West of Libya. Revolutionaries formed Military Councils based on regions and organized armed groups depending on their loyalty to a tribe, ethnicity or group, such that the post-revolution militia structure is designed based on a mixture of tribes, cities and ethnicities. For instance, Tripoli was divided into 13 zones. Factors such as population, city structure, and level of threat were taken into consideration. ${ }^{26}$ In each zone, there was a Command Council, composed of two revolutionary army officers (former Libyan Army officers) and three civilians. Each Command Council had an instruction document, only three pages long, as a standard operating procedure. This procedure was created by $67 \mathrm{rev}-$ olutionary officers (also former Libyan Army officers) and the papers were shared through fake social media accounts. ${ }^{27}$

Sheikh Sadiq al-Ghariani, the Grand Mufti of Libya, released a Fatwa on February 19, 2011, encouraging Libyans to mobilize, and peaceful demonstrations continued until August 20, 2011. Revolutionary forces were organized, armed, trained and motivated during this period. The operation to take Tripoli started on August 20, 2011. Three days later, on August 23, the seizure began both from inside and outside the city. A huge force from Misrata was able to reach the suburbs of Tripoli on the same day. The councils were responsible for confiscating the weapons from the army depots with the help of pro-revolutionary officers. ${ }^{28}$ The revolutionaries achieved victory in eight months. One problem that emerged after the revolution was that pro-regime formations continued to survive, even though the regime had been toppled. Meanwhile, discord between the revolutionaries grew after the victory. It was alarming to see tribalism, regionalism, and benefit-based formations that surpassed the obtained advantages of freedom after Qaddafi's diminishing regime.

\section{Challenging the Revolution}

Libya's inability to build a security architecture after the revolution can be blamed on many factors, although three of them appear to be the most significant: the state of Libya's security forces at the time, the nature of the revolution itself, and political/administrative issues.

The first factor, the state of Libya's security forces, can be assessed as the most important one, notably because of the lack of a command and control chain, but also because of the enormous number of officers who could not fulfill the prerequisites of the required security institutionalization because of a grossly inverted rank pyramid with a high level of aging, senior officers and very few junior ones. In addition to a lack of trained military personnel, morale, and 
motivation were low due to the erosion of trust in the military. The military, which had been designed to be passive and not threaten Qaddafi's regime, was unable to be an effective force after the revolution.

When the insurrection began in 2011, Libya's security forces were caught between providing support to the revolutionaries or to pro-Qaddafi forces. ${ }^{29} \mathrm{Ac}-$ cording to some estimates, approximately 70 percent of Libya's security forces remained neutral because of the prevailing sense of insecurity and distrust of any of the parties. Furthermore, the security forces genuinely lacked the capacity to respond to either side due to the lack of self-confidence intentionally instilled by the Qaddafi regime. The other 30 percent mostly supported the armed groups with only a very small number aligning with Qaddafi's Protection Forces. ${ }^{30}$ Thus the security forces, which were already hesitant and discredited, were pushed to the back row while the armed groups, led by low-level regional commanders, dominated the security realm. The widespread humiliation of former officers led them to position themselves in Haftar's military structure after his arrival in Libya, while the lack of strategic military training and experience made the armed groups uncoordinated, self-concerned and fragmented..$^{31}$

The second factor, the nature of the revolution itself, can be delved into by analyzing a series of complex factors. One issue was that the revolutionaries seized military garrisons and started their own codes of conduct, which were independent of each other and varied between cities. Simultaneously, the revolutionaries appropriated equipment and ammunition from the arsenals even though some inventory -mainly aviation, air defense, heavy armaments and logistical units- were destroyed during the conflict. The revolutionaries, lacking formal security experience, did not have any vision for restructuring the existing security forces. Nonetheless, these fighters had the perception that they were superior in comparison to the regular military due to the negative image of the security forces inherited from the Qaddafi era. ${ }^{32}$ Once the revolutionaries had taken over the military bases and police stations, they seized whatever arms they could, including tanks. As a result, a significant amount of military equipment was in the hands of armed groups, but not under any real control of Libya's "legitimate" governing institutions.

Qaddafi's legacy further compounded these problems; since he had abolished the Ministry of Defense, there was no longer a tradition or perception of this concept in Libyan minds. Because of this, the freshly established Minister of Defense formed additional military units that were outside the control of the General Staff, leading to conflict among decision makers as to their powers and responsibilities. The turbulence resulting from the revolution caused politics and the armed elements to become further intertwined. The armed groups accumulated more power after receiving a share of influential appointments. ${ }^{33}$ 
Yet the Libyan state could not build any institution to absorb, restructure or demobilize the armed groups, despite minor attempts. To compound this problem, unemployment deepened the disorder, as unemployed Libyans had to join either the security forces or the armed groups to earn a living.

Another factor that led to Libya's non-institutionalization was the lack of national-level leadership during the revolution. There was neither a coordination mechanism nor a coordinated effort among the revolutionaries. Their activities were very dependent on regional dynamics at a high local level. Hence, there was no common vision, program or

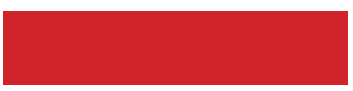

\section{The regionalization of the revolution,} based on city and tribe solidarity, impeded a countrywide transition from the conditions of the revolution to a consolidated state collective action to conclude the revolution by establishing commonly agreed-upon institutions. Meanwhile, individuals who did not participate in the revolution joined the armed groups afterward to benefit from its outcomes, and produced interest groups that flourished to realize their own ambitions, not the goals of the revolution. ${ }^{34}$ Thereby, Qaddafi's strategy of sustainable anarchy found life after the revolution.

The initial attempt toward institutionalization resulted in the establishment of the General National Congress by means of an election other than building the Supreme Security Committee (SSC) and the creation of the Libya Shields Forces. The Libyan people elected 200 representatives who were mixed in terms of their ideological motivations. However, the revolutionaries, who perceived themselves as deserving the success of the revolution, dominated politics while distancing themselves from the Armed Forces because they were afraid of a possible coup d'état. This fear led the revolutionaries not to restructure the defense institutions, a situation that was compounded by the fact that the decision-making process was congested. ${ }^{35}$

In accordance with the political turmoil, the Law of 2012 and 'Political Isolation Law' of 2013 required all governmental offices to be cleansed of the officials who had worked during the Qaddafi era. ${ }^{36}$ This decision was a turning point in dividing the revolutionaries, since the initial attempt at eliminating only high-level officials turned into a clearance of most officials who had served after 1969 during the Qaddafi era. This decision turned out to be polarizing and a further opportunity for the armed groups to justify their presence by providing security either to the local public or to political figures. Moreover, pro-Qaddafi groups were still on the Libyan scene, which complicated the political picture. Meanwhile, the race to trade and possess weapons became a priority for many of the groups. ${ }^{37}$ The chaos of Libyan politics made the victory of the revolution appear to be a failure. 
The armed groups, for their part, are more prone to be loyal to regional leaders than to a hierarchical, centralized chain of command
Consequently, Libya's non-institutionalization after the revolution can be linked to two interconnected failures. The first is the inability to manage the transition period. The revolution had started within the limited organizational skills of the Military Councils. The Councils were not efficiently integrated under a central leadership, most probably due to fear of having another 'Qaddafi', the speed of the revolution and the lack of a tradition of working together. The prevailing mood of the revolutionaries was to topple the regime and create an accountable state system. The regionalization of the revolution, based on city and tribe solidarity, impeded a countrywide transition from the conditions of the revolution to a consolidated state. Hence, the second non-institutionalization factor is the failure to establish not only order but also a system for the state. Additional factors multiplied the negative impact of the revolution, rather than creating the desired outcomes, because of the presence of competing groups seeking more power, foreign incursion via these armed groups, corruption or the political agenda of personal benefit. ${ }^{38}$ Nonetheless, building an 'institutionalized' system remains the best long-term exit strategy from state failure in Libya.

The third factor to be considered is the lack of 'political and administrative will' to govern the post-revolution era. The new government attempted to coopt the armed groups to bring them under its control; however, the reality was that the armed groups controlled the institutions. ${ }^{39}$ The political and administrative bodies showed no intention of building an institutionalized security sector. Both the military and the revolutionaries benefitted from the chaotic situation in the security sector, polarizing themselves and/or giving their loyalty to a political or armed group.

\section{Security Architecture and Concerns}

The strategic architecture of the Libyan regular security forces is an essential issue that is being handicapped by various impediments, the first of which is the blurring lines of authority and duplication of institutions leading to inefficient security procedures. Friction has arisen between the Ministry of Defense and the Armed Forces General Staff as to their mandates, although neither has well-established institutions on the ground. The strategic demarcation of authority and responsibility is specified by Law No. 11 of 2012 and its 2015 amendments. ${ }^{40}$ The President is identified as the Commander in Chief and the respective responsibilities of the Minister of Defense and Chief of General Staff are defined. The further amendment establishes the post of General 


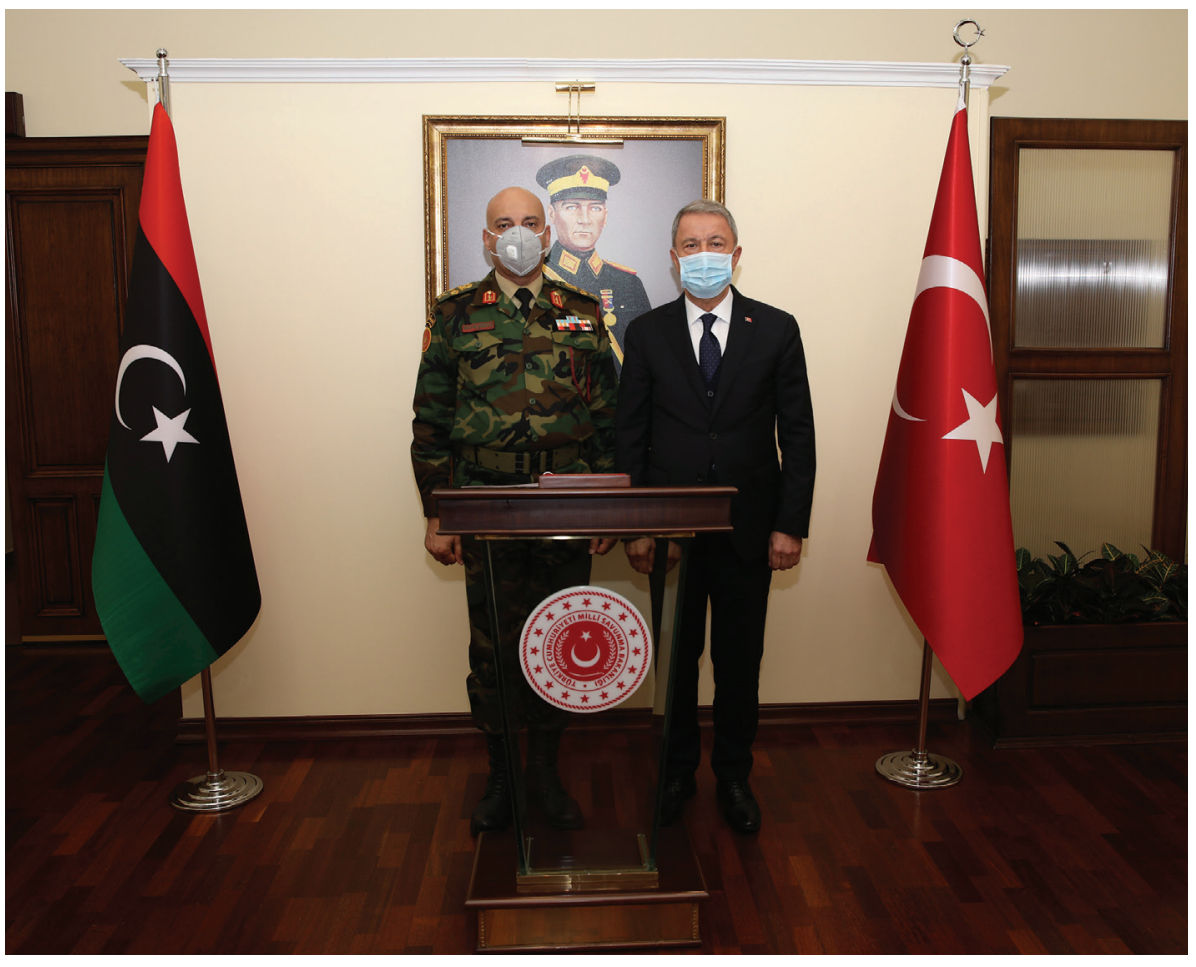

Commander, separate from these offices. ${ }^{41}$ Law No. 11 and its amendment do not have any position of "General Commander." The House of Representatives promulgated another decision creating the chain of command through the President, General Commander, Minister of Defense, and Chief of General Staff, respectively. The title was explicitly created for Haftar to ease the escalation of tension while his self-styled Army has its own Chief of General Staff in Benghazi. The General National Congress ratified its own decision on this chain of command after its mandate had run out, criticizing it on the grounds of the invalidity of the General Commander, while the Constitutional Court declared the House of Representatives to be an illegitimate body. ${ }^{42}$

Besides the lack of clarity over the organization of the higher echelons of Libya's security structure, another issue that came to light after the February 17 Revolution was the non-existence of an actual Libyan Armed Forces and an efficient policing system. It was therefore somewhat absurd to fight for more authority over Libya's security forces, since they mostly existed only on paper. The real security providers were, and still are, the armed groups, while the chain of command over the armed groups has lost (or failed to establish) its grip/power. Regionalism has proven too strong to achieve national-level reorganization and reformation. ${ }^{43}$
Turkish National Defense Minister Hulusi Akar receives Chief of Staff of the Armed Forces of Libya, Mohamed Ali al-Haddad, in Ankara, Turkey on October 19, 2020. ARIF AKDOĞAN / AA 
The revolution and the concurrent turmoil forced the armed groups to enlarge their numbers and obtain financial resources to maintain their organization by establishing control over critical institutions and regions
The post-revolution era has witnessed an authority complication upon the Libyan strategic security architecture. ${ }^{44}$ The Government of National Accord (GNA), which is recognized as Libya's sole legitimate governing body by the $\mathrm{UN}$, directs the Ministry of Defense, although the Libyan General Staff, Military Judiciary, and Defense Industry Institutions have their own lines of authority. The operation rooms, which can be likened to Regional Commands, are directly linked to the Prime Minister (PM), rather than the Minister of

Defense, as Commander in Chief. These forces consist of the armed groups under the authority of either the Ministry of Defense, the Ministry of Internal Affairs or the PM's Office. On the other hand, Haftar's self-styled army is subject to a parallel organization situated in Benghazi that challenges the authority of the GNA, while cooperating with pro-Qaddafi armed groups, African mercenaries, Egyptian military units and a Russian private military company. The armed groups, for their part, are more prone to be loyal to regional leaders than to a hierarchical, centralized chain of command. Therefore, post-Revolution Libya has become a divided country in terms of defense institutions. As the relationships are blurred on paper and in practice, the structure of the defense sector appears complicated, particularly given that the armed groups have their own chain of command and control.

This complex situation has resulted in cracks in the chain of responsibility at the strategic level, which are transmitted to the midlevel military formations, including the armed groups associated with the military. The personalities of the high-ranking decision makers hold more weight than their designated authority to allot funds or withhold resources to mobilize or stall the military units if their political agendas differ or conflict.

\section{The Libyan State and Non-State Armed Groups}

The current picture of the armed groups is complicated, but also easy to portray. It is complicated because the armed groups are free to choose any major power broker, to be loyal to Tripoli's GNA or Benghazi, which makes it hard to predict with whom they will play along. Micro-level neighborhoods are protected by certain armed groups not to be challenged without an armed clash. The regionalization of the groups is apparent, with groups generally aligned to the cities from which they come. The armed groups of these cities mobilized 
themselves to expand their area of influence, which created competition with others for certain facilities, institutions or neighborhoods. They may also enjoy the support of external powers that help them increase their capacities and vie with their competitors for superiority. ${ }^{45}$

When Qaddafi was removed from power along with his Protection Units, the armed groups had two options for their future. Some members of the armed groups returned to their ordinary lives as civilians, while those who were unemployed or in need, along with those with great ideological or regional identity consciousness, continued their security activities. Distrust toward the inactive formal security forces made it easy for these armed groups to build independent security systems in their neighborhoods not only to protect their families, but also to intervene in neighboring regions to prevent other groups from dominating. Ideologically and psychologically, Tripoli seems to be the main prize for which many actors compete in order to maintain influence and deter others.

The revolution and the concurrent turmoil forced the armed groups, first, to enlarge their numbers and obtain financial resources to maintain their organization by establishing control over critical institutions and regions. The greater the control that the armed groups have over 'their' neighborhoods and regions, the more money they can make to finance themselves. Inevitably, the armed groups started to compete with each other to capture and hold key locations in order to establish or expand their strength and influence.

After common ground was reached through the Libya Political Agreement of 2015 (Skhirat) and Haftar launched Operation Dignity (Karama) to seize Western Libya, the armed groups of the Western cities, despite their scattered nature in terms of loyalty and ideological motivations, formed new coalitions. ${ }^{46}$ They attached themselves to higher but still local authorities, while embedding themselves within the Ministry of Defense, Ministry of Interior, Presidential Council, or Haftar's forces. By so doing, they further increased their numbers, allowing them to more effectively display strength and ensure their regular payment. The Central Bank, which is responsible for the payrolls, directly paid the wages without asking if the group was legitimate, functioning or to whom it was loyal. ${ }^{47}$ The Libyan state thus gave the revolutionaries more legitimacy, with monthly payments as if they were Libya's regular security forces, through resolutions issued and backed by politicians. ${ }^{48}$

The legitimized armed groups appeared to be able to procure equipment simply by a 'letter of intent' and pay for it with funds from the government. Furthermore, the ease with which regular payments were allocated encouraged Libyans to enroll in any group or even in several groups and government forces to receive multiple salaries. As can be expected, hyperinflation in the 


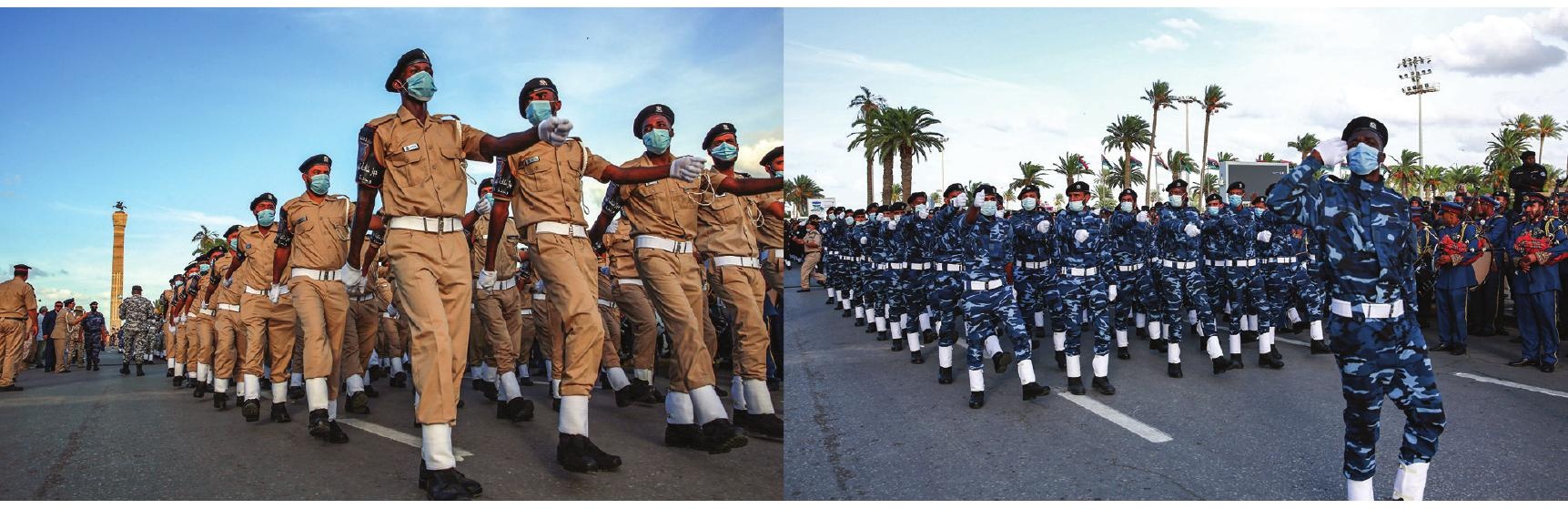

Security forces of Libya's

UN-recognized GNA march during an official parade commemorating Police Day at the Martyrs'Square in the GNA-held capital Tripoli on October 8, 2020. MAHMUD TURKIA / AFP via Getty Images

number of the revolutionaries occurred, even though a substantial number of them had not participated in the revolution. Furthermore, external support to certain groups in the form of high salaries ensured the loyalty of officers and some revolutionaries shifted to groups that enjoy additional resources from rich Gulf countries. ${ }^{49}$ Further, the armed groups are using corrupt methods to make even more financial gains; the monopoly of banks to sell foreign exchange offered the opportunity to the armed groups to make extra money by establishing control over the banks. ${ }^{50}$

After realizing that it was necessary to reform the armed groups, leading political figures reviewed their status and attempted to reorganize them by integrating or terminating their status. Reform attempts started with the idea of integrating Shield Forces into a more regular security architecture through three phases. The first phase was to employ them as a military force under the General Staff. Shield Forces accepted this proposal on the condition that they would be supervised by an officer who had participated in the revolution. The second phase of the integration was to ask the members of the groups to declare their weaponry, have them stored after an inventory making process, and give them the choice to take part in the integration process or leave the military to return to their civilian life. The final phase was to have the armed groups organized as regular military units with an offer of regular payments made afterward. ${ }^{51}$

The armed groups massed various forces after the revolution to strengthen their presence in key cities. Some previous efforts had been made to have the armed groups integrate, and different responsibilities had been assigned to different armed groups during and immediately after the revolution. The year 2014 witnessed the abolishment of these formations by Libyan Shield Forces, the Central Security Organization, the Tripoli Revolutionary Battalion and the Special De- 
terrence Forces. Organizations that were supposed to be transitory appear to be permanent, since the end of the transitional period has yet to materialize. ${ }^{52}$

\section{Conclusion}

The major causes for Libya's lack of security are lack of political will and competition among the armed groups to grab more influence. All of the actors want

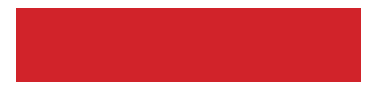

Local armed groups assume the role of providing security at the local level to fight against crime to seize a share of the state mechanism by establishing an area of influence in their regions. This scramble for authority has crippled the reform and reorganization attempts of previous years. Once a measure to build a security system was taken, another security institution was formed to replace it. Attempts to build an organization were labeled as 'temporary' or 'transitional,' reflecting the lack of trust in the minds of other actors.

The state structure itself contributed to the lack of political will and the weakening of the security structure in Libya. ${ }^{53}$ Disorder has undermined the authorities and blurred the responsibilities of the strategic decision makers at the ministerial and supreme military leadership levels. Qaddafi's legacy of getting rid of the Ministry of Defense and neutralizing the military has led to defective traditions and a lack of necessary regulation in order to have proper command-control relationships and organization. The refusal of the armed groups to answer to appointed authorities that they do not approve of has resulted in shortcuts in the hierarchical order that endanger the architecture of the state.

The revolution has had two tangible outcomes to date. The first is the erosion of trust in the discredited state apparatus. Power-sharing concerns after the revolution, which itself relied on regional and ideological motivations, further eroded trust in the state. Armed groups that had been allied during the revolution had their differences exacerbated through the influence of external actors. Transparent and accountable state-building efforts are therefore vital for building trust and starting any type of reform. The second field is the split between the revolutionaries and the officers from the old Libyan Armed Forces. Qaddafi's practice of neutralizing the Armed Forces to ensure the safety of his regime, and the passive attitude of some officers toward the revolution did not inspire trust in the eyes of the revolutionary forces. Therefore, the armed groups did not accept the authority of the former officers, and many officers pledged loyalty to Haftar in order to regain a sense of worth.

Qaddafi's legacy to have a nation incapable of challenging his regime has left not a system but many sub-systems in Libya, leading to a fractured state. This is evident in the proliferation of the armed groups, with divergent regionalized 
Polarization in the security field and the incapacity of the formal security forces strengthen the perception that the armed groups are the only viable security providers

or ideological motivations, seeking to advance themselves over others. To that end, these groups have attempted to influence, threaten or coerce the political and administrative authorities. In such a quagmire, the armed groups are naturally inclined to engage in competition with each other.

This inefficient state results in a strategic problem with a dysfunctional hierarchy in which it is unclear who is linked to whom, and who is authorized or responsible for what. Some military units report directly to the Prime Minister, while armed groups are certified by the Minister of Defense and military units fall under the authority of the General Staff. The status of the police is no different, since they are linked to municipalities, which weakens central control. Local armed groups assume the role of providing security at the local level to fight against crime. Despite the Ministry of Internal Affairs' increased efforts for unity, the scattered policing system is not adequately integrated to deter the proliferation of countrywide, armed criminal groups.

Polarization in the security field and the incapacity of the formal security forces strengthen the perception that the armed groups are the only viable security providers. Once the armed groups are included in the state mechanism by the decree of a strategic decision-maker, they obtain a certain legitimacy, but lack the requisites of institutionalization. On the other hand, the mutual distrust of the armed groups means that the security pockets they have established throughout Libya encumber the freedom of movement that is essential for a state in order to maintain liberty, prosperity and a sense of community. In short, armed groups are vital to building security in Libya, a fact that should encourage the state to enroll them lest they continue to challenge state authority. Such a fact of existing security architecture requires a thorough and wellplaned security reform to ensure the unity of the Libyan state.

\section{Endnotes}

1. Waniss A. Otman and Erling Karlberg, The Libyan Economy: Economic Diversification and International Repositioning, (New York: Verlag Berlin Heidenberg, 2007), p. 304.

2. Peter Cole and Brian McQuinn, The Libyan Revolution and Its Aftermath, (Oxford: Oxford University Press, 2015), p. 226.

3. All the interviwes in this research article were conducted by the author himself and approved by the ethical commitee of Hasan Kalyoncu University on November 10, 2020, No. E--804.01-2011100027; The names of the interviewed Libyans have been changed to protect their identity and their security.

4. Interviewee 1, "Current Security Structure in Libya," (July 16, 2018).

5. Nicholas Hagger, The Libyan Revolution: Its Origins and Legacy: A Memoir and Assessment, (London: O Books, 2009). 
6. Christopher M. Blanchard, "Libya: Background and U.S. Relations," Congressional Research Service, (August 3, 2009), retrieved from https://www.everycrsreport.com/files/20090803_RL33142_783e1fb1062d70d7807ae92ced99d1d55e8175d4.pdf.

7. "Current Security Structure in Libya."

8. Interviewee 1, "Current Security Structure in Libya."

9. Interviewee 1, "Current Security Structure in Libya."

10. Interviewee 1, "Current Security Structure in Libya."

11. Andre Netto, Bringing Down Gaddafi: On the Ground with the Libyan Rebels, (New York: Palgrave McMillan, 2014), p. 46.

12. Interviewee 1, "Current Security Structure in Libya."

13. Interviewee 2, "Security Sector in Libya: A Historical Process," (September 9, 2018).

14. Interviewee 2, "Security Sector in Libya: A Historical Process."

15. Bukola A. Oyeniyi, The History of Libya, (Santa Barbara: Greenwood, 2019).

16. Interviewee 2, "Security Sector in Libya: A Historical Process."

17. Interviewee 3, "Promoting Security in Libya," (September 9, 2018).

18. Interviewee 2, "Security Sector in Libya: A Historical Process."

19. Interviewee 1, "Current Security Structure in Libya."

20. Interviewee 3, "Promoting Security in Libya."

21. Interviewee 1, "Current Security Structure in Libya."

22. Ali Abdullatif Ahmida, Making of Modern Libya: The State Formation, Colonization, and Resistance, (New York: Sunny Express, 2009), p. 56.

23. Interviewee 1, "Current Security Structure in Libya."

24. Interviewee 1, "Current Security Structure in Libya."

25. Interviewee 4, "How did the Revolution Evolve?" (October 10, 2018).

26. Interviewee 4, "How did the Revolution Evolve?"

27. Interviewee 4, "How did the Revolution Evolve?"

28. Interviewee 4, "How did the Revolution Evolve?"

29. Richard A. Lobban Jr. and Chris H. Dalton, Libya: History and Revolution, (Santa Barbara: Praeger, 2014), p. 83.

30. Interviewee 5, “Dynamics of a Probable SSR," (September 18, 2018).

31. Interviewee 6, "Perspective of Youth on the SSR," (October 18, 2018).

32. Interviewee 3, "Promoting Security in Libya."

33. Interviewee 3, "Promoting Security in Libya."

34. Interviewee 5, "Dynamics of a Probable SSR," (September 18, 2018).

35. Interviewee 2, "Security Sector in Libya: A Historical Process."

36. For full text, see Legislation No.13 of 2013 [on] Political and Administrative Isolation, "Libya's Political Isolation Law," Muftah, retrieved from http://muftah.org/full-text-libyas-political-isolation-law/\#.VolMb1IYq4Q.

37. Interviewee 2, "Security Sector in Libya: A Historical Process."

38. Interviewee 6, "Perspective of Youth on the SSR."

39. Interviewee 1, "Current Security Structure in Libya."

40. "The National Transitional Council-Libya, Law No. (11/2012): Regarding some of the Provisions Related to the Leading Positions in the Libyan Army, Issued in Tripoli on Monday, January 13, 2012," retrieved 
from https://security-legislation.ly/sites/default/files/lois/317-Decison $\% 20$ No.\%20\%2820\%29\%20of\%2 02015_AR.pdf.

41. "The National Transitional Council-Libya."

42. Interviewee 7, “Libya's Security Structure," (August 31, 2018).

43. Interviewee 8, "Ministry of Internal Affairs and Police," (December 28, 2018).

44. Tim Eaton, Abdul Rahman Alageli, Emadeddin Badi, Mohamed Eljarh, and Valerie Stocker, "The Development of Libyan Armed Groups Since 2014: Community Dynamics and Economic Interests," Chatham House, (March 2020), retrieved from https://www.chathamhouse.org/sites/default/files/CHHJ8001-Libya-RP-WEB-200316.pdf.

45. Interviewee 8, "Ministry of Internal Affairs and Police."

46. Christopher Thornton, Libya on the Brink and How to Pull It Back: Options for International Actors, (Riyad: King Faisal Center, 2015), p. 15.

47. Interviewee 8, "Ministry of Internal Affairs and Police."

48. Interviewee 9, "Thuwwar: Way Ahead," (January 3, 2019); Interviewee 10, "Security in Libya," (October 9, 2018); Interviewee 11, "Security in Libya," (December 1, 2018).

49. Interviewee 7, "Libya's Security Structure."

50. Interviewee 8, "Ministry of Internal Affairs and Police."

51. Interviewee 7, "Libya's Security Structure."

52. Interviewee 7, “Libya's Security Structure."

53. Interviewee 13, "A Historic Look to the Security Structure of Libya," (July 16, 2018); Interviewee 12, "Southern Libya: Third Dimension of SSR," (January 16, 2018). 